\title{
Research on the Construction of Tourist Talent Cultivation System in Jilin Province from the Perspective of Global Tourism
}

\author{
Yanjie Zhan \\ College of Business Administration, Tonghua Normal University, Tonghua, China \\ 82509380@qq.com
}

Keywords: Global tourism; Jilin Province; Tourist Talent Cultivation

\begin{abstract}
In today's society, tourism has become a strategic pillar industry in our country. The promotion and development of global tourism requires tourism talents to master more extensive and updated knowledge and skills, and put forward greater demand for 'high, excellent and new' talents. This has put forward new requirements for the cultivation of tourist talents. At present, the phenomenon of mismatch of demand and supply of tourist talents in Jilin province is relatively prominent. Through the analysis of the structural contradiction between supply and demand of tourist talents in Jilin province and its causes, and the research on the construction of the tourist talents training system in Jilin Province, the author puts forward the construction of a diversified training platform and the optimization of the tourist talents training structure. It will provide talent support for global tourism and promote the innovative development of tourism throughout Jilin Province.
\end{abstract}

\section{Introduction}

At the two sessions in 2017, global tourism made its debut in the government's work report, which brought great benefits to the development of global tourism. In 2016, the National Tourism Administration announced the establishment of the first batch of 262 "National Global Tourism Demonstration Zones". Jilin Province includes 15 cities and counties including Jilin City, Changbai Mountain, Changchun Jingyue High-tech Zone, Jiutai District, and Shuangyang District. District) has become the first batch of national tourism demonstration areas to establish units. In the current situation of tourism panorama, full-time, Universal, and full-industry, the continuous emergence of new forms of tourism and the six main tasks of tourism development proposed in the National "13th Five-Year Plan" plan have all put forward new requirements for the training of talents in tourism education. Therefore, how to train tourism talents with higher quality to optimize the supply level, upgrade the tourism vocational education level, train multi-level talents, and propose structural reforms to the industry talents training system has become a major issue that needs to be urgently solved by the majority of educators.

\section{The Demand for Tourist Talents in Jilin Province from the Perspective of Global Tourism}

In 2017, Jilin province took the lead in pushing forward the supply-side structural reform of tourism. The industrial pattern is more open. The space layout of the dual-core, three-zone, and four-boutique tourism belts has been formed, and the industrial development pattern of "linking winter and summer, driving spring and autumn, and driving the whole year" has been formed, and the product system has been improved. In 2017, the total number of tourists received in Jilin Province was 19,241,300, an increase of $16.06 \%$ year-on-year; The total tourism revenue reached 350.704 billion yuan, an increase of $21.04 \%$ year-on-year[1]. The rapidly developing tourism economy will accept more talents for employment. At the same time, it will require a large number of high-quality tourism talents with professional tourism knowledge and skills, and are good at tourism management and management.

Talent Scale Requirements Forecast. At present, from the trend of tourism economic development in our province, the number of tourists such as outbound tourism, inbound tourism, and domestic tourism in the province will continue to maintain a sustained momentum of growth, and the number of tourism-related enterprises is also rapidly increasing. The construction of the global tourism demonstration area has led to the rapid increase in the number of tourist attractions and hotels and the 
continuous expansion of scale. With the increasing rate of self-driving travel, the demand of self-driving travel related service enterprises for tourist talents is also increasing. Therefore, Jilin Province needs a large number of tourism professionals in the process of establishing a global tourism construction to provide the necessary talent protection and intellectual support for the development of tourism in Jilin Province.

Need a Large Number of Integrated Talents. From the perspective of global tourism, tourism is not only about the six elements of traditional tourism. At present, the tourism industry in Jilin Province is integrated with other industries. The new tourism industry has integrated many elements, including agriculture, real estate, and industry, and the coverage of the industries involved is more extensive. The new marketing model and intelligent tourism involve the integration of multi-disciplines and tourism, which puts forward higher requirements for tourism-related practitioners. At present, the tourism comprehensive talents needed are not the simple tourism service talents in the traditional sense, but the comprehensive talents that need to understand the practice, have the innovation consciousness, and can adapt to the development of the tourism and market needs of the whole region[2].

Top and Middle Management Talent in Need. At present, Jilin Province has become more and more famous and influential in tourism, and it has changed from the stage of high-speed tourism growth to the stage of high-quality tourism development. In this development process, not only needs a large number of frontline services and operators, but also a large number of middle and senior management and management talents. Judging from the current development of tourism in Jilin province, we urgently need talents in tourism human resources management, advanced tourism marketing, memberships and club management, and tourism Capital Management and management personnel in the middle and senior levels.

\section{Problems in the Cultivation of Tourist Talents in Jilin Province from the Perspective of Global Tourism}

The development of tourism in Jilin province is in urgent need of the development of tourism talents education. In recent years, the education scale of tourist talents in Jilin Province has also been continuously expanded. From the general point of view, although the tourist talent education system has been continuously improved, the current tourist talent education still can not meet the needs of tourism development. This is reflected in the following four areas:

Inadequate Supply of Tourism Professionals. Facing the rapid growth of the tourism market, the growth of tourism professionals in Jilin province is slow. The majority of the tourist talents in Jilin province are service-oriented and skilled, and there are still fewer middle and senior management talents. In particular, there is a serious shortage of middle and senior management personnel, middle and senior tour guides, travel planners, and tour planners who are skilled in the outbound travel business[3]. Such as tourism e-commerce talents and small language excellent tour guides such as involved in the interdisciplinary talents are in short supply. The number of tourism colleges and universities in Jilin province is much lower than that of other provinces, which can not meet the market demand well. By the end of 2017, there were 18 undergraduate colleges and universities in Jilin Province(including tourism management, hotel management, exhibition economy and management), 20 colleges and universities, and 8 secondary vocational schools, with a total of 46. The details are shown in table 1. 
Table 1 Schools with tourism specialty in Jilin Province

\begin{tabular}{cc}
\hline Level of institutions & Name of institution \\
\hline Undergraduate & Jilin Engineering Normal University, Jilin Agricultural University \\
institutions & University, Beihua Changchun Normal University, Tonghua Normal \\
University, Jilin Normal University, Jilin Normal University, Jilin \\
University, Jilin University of Foreign Languages, Jilin Business School, \\
Changchun University, Yanbian University, Changchun Guanghua \\
College, Changchun University of Finance and Economics, Changchun \\
Institute of Science and Technology, Boda College of Jilin Normal \\
University, Tourism College of Changchun University, Jilin Art College \\
Jilin University(Nanhu Campus), Yanbian University, Changchun \\
Normal University(Anime Training Base), Jilin Institute of Technology, \\
Liaoyuan Vocational and Technical College, Changchun Information \\
Technology Vocational College, Songyuan Vocational and Technical \\
College, Jilin Railway Vocational and Technical College, Changbai \\
Mountain Vocational and Technical College, Yanbian Vocational and \\
Technical College, Jilin City Vocational and Technical College, Jilin \\
Vocational and Technical College, Jilin Electronic Information \\
Vocational and Technical College, Jilin Vocational and Technical \\
College Engineering Vocational College, Changchun Vocational and \\
Technical College, Changchun Guanghua College, Changchun Institute \\
of Science and Technology, Jilin Normal University Boda College, Jilin \\
Provincial Economic Management Cadre College \\
Jilin Railway Economics School, Jilin Provincial Agricultural School, \\
Jilin Electronic Information Institute, Changchun Agricultural School, \\
Jilin Mechanical and Electrical Engineering College, Jilin Economic and \\
Trade Vocational Secondary Professional School, Changchun \\
International Trade Aviation Passenger Service Secondary School, Jilin \\
City Women's Vocational Secondary School \\
\hline Secondary vocationals \\
schools
\end{tabular}

Travel Talent Mobility and Brain Drain are Increasing. On the one hand, the tourism industry in Jilin province is in short supply, on the other hand, along with the rapid socio-economic development of Jilin province and the fierce competition in tourism industry, the flow of tourism workers has obviously intensified, especially the loss rate of tourism senior talents is very high. According to statistics, the normal loss of personnel in the general industry is about $5 \%-10 \%$, and the loss rate of employees of tourism enterprises is as high as $20 \%$. According to the survey, the staff turnover rate of many tourism companies is more than $25 \%$, and some hotel staff turnover rates even exceed $40 \%$. The most frequent are tour guides of travel agencies and young general managers, department managers, and supervisors of star hotels. Wait. There are many reasons for the brain drain. First, because of the low recruitment requirements for employees(especially hotels), many people will initially enter the industry, but after two or three years of work, many employees have become familiar with the business and accumulated certain resources. Will be separated from the company they work for, find another job or start their own business. Second, the characteristics of the tourism industry itself. Tourism is a service-oriented industry. The reasons for the high intensity of labor, the high pressure of work, and the low social status cause some tourist talents to flow to other industries. Third, some tourism enterprises human resources management concept lagging behind, the re-introduction of talents, light training, lack of attracting and retaining the environment of talent, leading to a lot of middle and senior management talent job-hopping[4].

Uneven Distribution of Tourist Talents. The uneven distribution of tourism talents is mainly reflected in two aspects: First, the distribution of high-level tourism talents is uneven between regions. Most tourist talents are willing to work in cities or regions with rapid economic development and good 
tourism development. They conducted a survey of undergraduate graduates of tourism majors in Jilin Province. The results showed that $28 \%$ of people are more willing to choose cities such as Beijing, Shanghai, and Guangzhou to develop. Such tourism is considered to have more opportunities and more room for development. $52 \%$ of people are willing to choose to stay in Jilin Province, but they are only willing to stay in Changchun, the provincial capital, and $18 \%$ are willing to choose to stay in such prefecture-level cities as Jilin City, Siping City, and Yanji City. Only $2 \%$ of people think that as long as the job is satisfactory. This is also one of the reasons why the areas such as Songjiang River and Erdao Baihe in Jilin Province urgently need high-level tourist talents. Second, the distribution between industries is uneven. Hotels, travel agencies and tourist attractions are more attractive to talents, while tourism e-commerce, exhibition planning, tourism planning, etc. are relatively developed.

\section{Construction of a Multi-plex Tourism Talent Cultivation System in Jilin Province from the Perspective of Global Tourism}

To promote the development of tourism in Jilin Province and solve the problem of tourism talents of Jilin people, the following aspects can be used to construct the tourism talents training system in Jilin Province:

Establish a Tourism Talent View. In the process of tourism talents development, governments at all levels should not only increase investment in tourism infrastructure, but also increase investment in tourism talents development and utilization. It is necessary to firmly believe that talents are the first tourism resources[5]. Tourism administration departments and education, personnel, finance, social security and other relevant departments should coordinate vigorously so that tourism education can properly take the lead in the development of tourism and reflect the strategic idea of "talent tourism". In particular, it is necessary to strengthen the training of key talents in the tourism industry.The first is to train professional tourism managers. Improve and optimize the knowledge structure and professional structure of senior management personnel in tourism enterprises, and improve the management level of tourism enterprises; We will increase the training of travel agencies, tourist attractions, tourist hotels and related tourism enterprises to enhance their marketing management and ability to participate in international competition. Second, we will focus on training professionals who are in short supply. At present, Jilin Province is in short supply of tourism talents mainly include hotel senior managers, tourism e-commerce talents, tourism planners, tourism planners and travel route designers. Third, step up efforts to train outstanding tour guides. Guided tours are an important window for the display of tourist images in Jilin province. Jilin province can increase the training of professional and professional ability of tour guides, improve the professional quality and service skills of tour guides, and actively strive to train middle and senior tour guides. You can also organize various kinds of guided tour competitions, tourism product design competitions, etc. to promote learning and improve the guidance of Jilin Province.

Establish an Incentive Mechanism for Tourism Talents. At present, Jilin province tourism, especially travel agency and hotel industry staff turnover rate is mainly caused by low social status, high physical labor intensity, overtime regularisation, low pay levels and other factors, then should retain staff, reduce staff turnover rate. We should make efforts mainly in the following areas.First, the relevant departments should make great efforts to raise the wages and welfare benefits of the employees of tourism enterprises, strictly comply with the state regulations on working hours, and protect the basic rights and interests of outstanding personnel. Second, we need to establish a mechanism for the introduction of tourism talents and improve the tourism training system. The competent tourism authorities at all levels should establish a reward system for tourism talents as soon as possible, and regularly reward tourism practitioners who have made outstanding contributions to the development of tourism[6]. We will improve the social status of tourist talents, create an atmosphere of respect for knowledge and talents, and provide protection for the legitimate rights and interests of tourist talents. Third, we will create a tourist talent network in Jilin Province to promote the development of the tourist talent market in the direction of networking and informatization. At the same time, it is also necessary to strengthen exchanges and cooperation with neighboring provinces to establish tourist talents exchange 
centers in the three provinces, share resources, and promote regional cooperation to ensure the supply of tourist talents.

Cultivate Master of Tourism Management. By the end of 2017, only Jilin Normal Changchun Normal University and Jilin Normal University had been approved to train Master of Tourism Management(MTA). This is far from satisfying the demand for talents in the development of tourism. Therefore, universities and government departments in Jilin Province should also strengthen their investment in talent development and training. The government departments should encourage universities to cultivate master's degrees in tourism management. At the same time, in the MTA training process, we must pay attention to the need for talents in the tourism industry, so that the industry can send high-level talents to meet the needs of the market.

Construction of Public Information Service Platform for Tourism Talents. At present, Jilin province does not have a public information service platform for tourism talents, improving the construction of regional talent information system, which is conducive to the allocation of tourism talent market and the rational adjustment of teaching resources in universities, and also helps the exchange of information on the needs of tourism talents, so as to achieve a smooth interface between talents and enterprises[7]. Through the platform, tourism education and tourism industry are organically linked, creating employment opportunities for tourism graduates, promoting the coordinated development of tourism education and tourism industry, realizing a virtuous circle, and providing a platform for tourism talents and employers to exchange services.

\section{Conclusions}

From a global tourism perspective, the construction of a tourism talent training system in Jilin Province is an important measure to ensure the supply of tourism talents in Jilin Province and achieve the healthy and orderly development of tourism in Jilin Province. It is up to the government, enterprises, institutions, teachers and other parties to work together and take practical measures. Can cultivate more Manchu Jilin Province tourism market development needs of professional talent.

\section{Acknowledgements}

This work was financially supported by The "13th Five-Year Plan" Project for Education Science in Jilin Province Key Issues for 2017 ([2017] No.427).

\section{References}

[1] Information on http://hn.ifeng.com/a/20171218/6236493_0.shtml(In Chinese)

[2] X.Zhang: Economic Research Guide, Vol. 21 (2008) No.2, p.189-190.(In Chinese)

[3] N.Wei: Times Finances, Vol.679(2017) No.11, p.38.(In Chinese)

[4] D. Wang: Study on the Development of Tourism Educaiton in Jilin Province (MS., Northeast Normal University, China 2011), p.2.(In Chinese)

[5] H.Zhao: Journal of Henan Business College, Vol.25 (2012) No.5, p.79-81.(In Chinese)

[6] W.Y.Cai: Modern education management, Vol. 6 (2018) No.2, p.194-196.(In Chinese)

[7] Y.J.Li: Journal of JiLin Business and Technology College, Vol. 27 (2011) No.2, p.17-19.(In Chinese) 